RESEARCH ARTICLE

\title{
Endosulfan (Thiodan $®$ EC 35) induced toxico-pathological effects in male Japanese quails (Coturnix japonica)
}

\author{
Ahmad Bilal Qamar ${ }^{1}$, Muhammad Zargham Khan ${ }^{1}$, Ahrar Khan ${ }^{1 *}$, Muhammad Kashif Saleemi ${ }^{1}$ and \\ Ijaz Javed ${ }^{2}$ \\ ${ }^{1}$ Department of Pathology, Faculty of Veterinary Science, University of Agriculture, Faisalabad-38040, Pakistan. \\ ${ }^{2}$ Department of Physiology and Pharmacology, Faculty of Veterinary Science, University of Agriculture, Faisalabad-38040, Pakistan.
}

Revised: 23 September 2011 ; Accepted: 18 November 2011

\begin{abstract}
The objective of the present study was to determine the toxico-pathological effects of endosulfan in Japanese quails. Male Japanese quails $(n=120)$ of 4 weeks of age were administered endosulfan in feed at 0 (control), 5, 25, 50, 100, and $500 \mathrm{mg} / \mathrm{kg}$ feed, respectively for 90 consecutive days. The quails of the $5 \mathrm{mg} / \mathrm{kg}$ group did not show clinical signs and had significantly lower values of feed intake, testes relative weight and leukocyte number than those of the control group. The quails of the 25 and $50 \mathrm{mg} / \mathrm{kg}$ groups had mild depression while those of the 100 and $500 \mathrm{mg} / \mathrm{kg}$ groups showed nervous excitation following ingestion of endosulfan. There was a dose related delay in onset of crowing, appearance of foamy material in the droppings and mounting upon the pen mates. The feed intake, body weight, erythrocyte and leukocyte counts, haematocrit values, and serum total proteins of endosulfan fed quails were significantly $(\mathrm{p}<0.05)$ lower than that of the control group. Serum testosterone levels did not change significantly in all the treatment groups. The liver of endosulfan fed birds exhibited fatty change of hepatocytes and necrotic foci in parenchyma. Testes of the endosulfan fed quails had lower weight, volume and diameter of seminiferous tubules compared with control birds. Degenerated spermatids and multinucleated cells were present in the germinal epithelium. Severity of haematological, biochemical and pathological alterations in quails increased with the increase in dietary endosulfan levels. In conclusion, endosulfan in Japanese quails had toxic effects upon liver, nervous, haemopoietic and reproductive system. Moreover, feed intake and body weight also decreased significantly suggesting general toxicity of endosulfan.
\end{abstract}

Keywords: Body weight, Coturnix japonica, endosulfan, haematological values, histopathology, Japanese quail.

\section{INTRODUCTION}

Pesticides have become omnipresent contaminants of our environment and have been found in soil, air, water and also in human and animal tissues worldwide (Ahmad et al., 2009). The range of the adverse health effects of pesticides include and are not limited to acute and persistent injury to the nervous, respiratory, reproductive, immune and endocrine systems and may also lead to birth defects and cancer.

Among the pesticides, endosulfan $\left(\mathrm{C}_{9} \mathrm{H}_{6} \mathrm{Cl}_{6} \mathrm{O}_{3} \mathrm{~S}\right)$, an organochlorine of the cyclodiene group is a broadspectrum agricultural insecticide. It is moderately persistent in the soil environment with a reported average field half-life of 55-277 days (Shalini et al., 2000). Endosulfan gains entry into the body via oral, pulmonary and dermal routes. Its toxicity is high in fish (Naqvi \& Vaishnavi, 1993) and high to moderate in rats (Reuber, 1981). In acute toxicity in rats, endosulfan causes stimulation of the nervous system, dyspnea and cyanosis (Naqvi \& Vaishnavi, 1993). Possible mechanism by which neurotoxicity develops could be that organochlorine intoxication produces neural damage (Slotkin et al., 2007). Organochlorine interact with y-amino butyric acid (GABAA) channels (Brannen et al., 1998) for the development of nervous signs.

Adverse effects of endosulfan upon the male reproductive system of rats include reduction in the weight of testes and accessory sex organs and inhibition of testicular functions (Chitra et al., 1999). Endosulfan residues have been detected in a variety of different wild and domestic mammalian species, fish and birds. Different species of birds collected from three agricultural areas with long histories of pesticide use in northwestern Mexico showed residues of endosulfan along with other pesticides (Mora \& Anderson, 1991). 
Endosulfan and other organochlorine pesticides have been detected in tissues of two fish-eating and one omnivore bird species in Argentina (Cid et al., 2007) and in vultures in India (Muralidharan et al., 2008). It is also assumed that endosulfan exposure of freerange poultry and wild bird population may occur through searching for food in endosulfan treated fields and ingesting contaminated grains, plant components or insects. The presence of residues in avian species suggests the plausibility of endosulfan to induce toxicopathological effects in these species. Garg et al. (2004a, b) conducted experimental studies in broiler chicks using low levels of dietary endosulfan $(2 \mathrm{mg} / \mathrm{kg})$ and reported its adverse effects upon the immune system, and some biochemical parameters including blood glucose, serum globulin and acetyl cholinesterase, alkaline phosphatase activity and total protein levels. This study also reported atrophy/hypoplasia, depletion of lymphocytes and haemorrhages in the thymus. In the femur, the zones of proliferating, maturing and degenerating, and calcifying cartilage cells were reduced in width. The metaphysis in treated birds showed a reduced number of cartilage cells. An experimental study reported immunotoxicological effects in broiler chicks induced by concurrent subchronic exposure to arsenic and endosulfan (Aggarwal et al., 2009). A poultry lymphocyte cell culture model has been described to determine zero-immunotoxic effect of endosulfan and chlorpyrifos and other pesticides in animals (Mehta et al., 2008).

In previous studies a wide range of endosulfan has been administered, ranging from $2-30 \mathrm{mg} / \mathrm{kg}$ feed to broiler chicks (Garg et al., 2004a,b; Aggarwal et al., 2009) and up to $4000 \mathrm{mg} / \mathrm{kg}$ body weight in quails (Prakash et al., 2009). However only scanty information was available in literature about dose and duration related endosulfan induced toxico-pathological effects in avian species. Thorefore, dietary levels varying from low $(5 \mathrm{mg} / \mathrm{kg})$ to high $(500 \mathrm{mg} / \mathrm{kg})$ were tested in the present experiment to observe the possible pathological effects in quails. Information about endosulfan induced clinical toxicity and toxico-pathological effects upon the male reproductive system, liver and kidneys of birds is scarce. With these observations, the present study was designed to evaluate the toxico-pathological effects of endosulfan in avian species. The Japanese quails (Coturnix japonica) were selected for this study because this species is extensively used as a model for different experimental studies and the results obtained may be extrapolated to other avian species.

\section{METHODS AND MATERIALS}

Experimental design: A total of 120 male Japanese quails (Coturnix japonica), $25 \mathrm{~d}$ old (95 to $105 \mathrm{~g}$ body weight) and apparently free from any clinical ailment were procured from a quail farm, randomly divided into 6 groups (20 birds in each group) and kept in metal wire cages at ambient temperature $\left(26 \pm 2{ }^{\circ} \mathrm{C}\right)$ in an animal house. The birds were fed on a corn soy basal feed containing $21 \%$ total protein (Khan et al., 2010). Five experimental feeds were prepared by the incorporation of 5, 25, 50, 100 and $500 \mathrm{mg} / \mathrm{kg}$ endosulfan (Thiodan ®35 EC, $32.9 \% \mathrm{w} / \mathrm{w}$ endosulfan: Aventis, Pakistan). After $1 \mathrm{wk}$ of acclimatization, the birds of the different groups were randomly offered experimental feeds. One group was kept on basal feed as the control. The food and water was given ad libitum. To observe the age and dose related changes in organs and serum, 5 birds from each group were humanely killed on day 15 and 30 while the remaining birds were killed on day 90 of the experiment. Killing of the birds was performed as per the Ethics Committee rules, University of Agriculture, Faisalabad, Pakistan, considering the national and institutional legislations regarding animal protection and welfare.

Clinical signs and behavioural alterations: As envisaged from literature, the salient features of endosulfan toxicity include neurotoxicity (Anand et al., 1986) and reproductive toxicity (Jaiswal et al., 2005). Therefore, for the present study, signs suggestive of nervous derangement (depression, excitation, attraction to feed) and those indicating onset of sexual maturity (crowing, passing of foamy material in the faeces and mounting upon pen mates) were taken into account and were subjectively evaluated twice daily. Based upon the severity and frequency, each clinical sign was subjectively scored from 0 to +4 . The body weight of birds of each group was determined on day 15, 30 and 90 of the experiment.

Pathological parameters: The birds sacrificed on day 15, 30 and 90 were examined for the presence of gross lesions on different organs. Organs including liver, kidneys, spleen, heart and testes were weighted and their relative weights were calculated as percent of the body weight. Testes volume was determined by fluid displacement method (Khan et al., 2008). Part of the liver and a cross sectional slice of about $5 \mathrm{~mm}$ thickness from mid portion of testes of each sacrificed quail was fixed in $10 \%$ neutral buffered formalin and processed for histopathological studies using the routine method of paraffin embedding (Awaad et al., 2010). Sections of $5 \mu \mathrm{m}$ thickness were stained with haematoxylin and eosin for microscopic study.

Haematological and serum biochemical parameters: The blood of each bird was collected prior to killing for haematological and serum biochemical studies. The 
haematological parameters included erythrocyte counts, total leukocyte counts, haematocrit and haemoglobin concentration (Jalees et al., 2011). The serum total protein concentration was determined by Biuret method and albumin by bromocresol dye binding technique. The serum testosterone levels were determined by an ELISA method (Testosterone ELISA, DRG ${ }^{\circledR}$ Instruments, GMBH, Germany).

Statistical Analysis: The results obtained were statistically analyzed by analysis of variance using a computer software package (MSTATC). Different group means were compared by Duncan's multiple range tests. The level of the significance was $\mathrm{p} \leq 0.05$.

\section{RESULTS}

\section{Clinical signs and behavioural changes}

A comparison of the clinical signs based on subjective evaluation is presented in Table 1. In the control and $5 \mathrm{mg} / \mathrm{kg}$ groups, no clinical signs and behavioural changes were observed. Crowing, appearance of foamy substance in faeces and mounting upon pen mates started on day 10 of the experiment. In the $25 \mathrm{mg} / \mathrm{kg}$ group, a few birds showed a mild degree of depression in the $1^{\text {st }}$ week.

Table 1: Effect of different dietary levels of endosulfan upon clinical signs and behavioural alterations in male Japanese quails

\begin{tabular}{lcccccc}
\hline Parameters & \multicolumn{7}{c}{ Groups } & & \\
& A & B & C & D & E & F \\
\hline $\begin{array}{l}\text { Depression } \\
\text { Excitation }\end{array}$ & 0 & 0 & +1 & +1 & 0 & 0 \\
$\begin{array}{l}\text { Decreased attraction } \\
\text { towards feed }\end{array}$ & 0 & +1 & +1 & +2 & +3 & +3 \\
$\begin{array}{l}\text { Delayed crowing } \\
\begin{array}{l}\text { Delayed mounting } \\
\text { upon pen-mates }\end{array}\end{array}$ & 0 & 0 & +1 & +2 & +3 & +4 \\
$\begin{array}{l}\text { Delayed appearance } \\
\text { of foamy material } \\
\text { in faeces }\end{array}$ & 0 & 0 & +1 & +2 & +3 & +4 \\
\hline
\end{tabular}

Variation from 0 to +4 denotes an increase in the severity of clinical signs (average of morning and evening score). Endosulfan levels in feed of groups A, B, C, D, E and F were 0, 5, 25, 50, 100 and $500 \mathrm{mg} / \mathrm{kg}$, respectively.
Overall attraction towards feed was less than that of the control group. In this group, crowing, presence of foamy material in the faeces and mounting upon their pen mates started from day 14 of the experiment. In the $50 \mathrm{mg} / \mathrm{kg}$ group, 3 to 4 quails showed mild degree of depression in the $1^{\text {st }}$ week of the experiment. Attraction towards feed was less than the control group. Crowing, presence of foamy material in the faeces and mounting upon their pen mates was observed from day 18 of the experiment. There were no difference in response to external stimuli in groups recieving 5, 25 and $50 \mathrm{mg} / \mathrm{kg}$ compared to the control.

In the $100 \mathrm{mg} / \mathrm{kg}$ group, all birds showed excitation and some birds attempted to fly in the cage. The birds responded intensely and nervously towards external stimuli compared to the control, 5, 25 and $50 \mathrm{mg} / \mathrm{kg}$ groups. Attraction towards feed was less than that of the control. Crowing, presence of foamy material in the faeces and mounting upon their pen mates started from day 21 of the experiment. In the $500 \mathrm{mg} / \mathrm{kg}$ group, nervous excitation of quails was more severe than that of the $100 \mathrm{mg} / \mathrm{kg}$ group. Birds attempted to fly in the cage and hit the ceiling and walls. Five birds in this group showed torticollis. Response towards stimuli was intense and nervous. Attraction towards feed in this group was lower than that of all the other groups. Crowing, presence of foamy material in the faeces and mounting upon their pen mates was observed from day 26 of the experiment.

\section{Body weights and endosulfan intake}

The body weights of quails (Figure 1a) in the 5 and $25 \mathrm{mg} / \mathrm{kg}$ groups on day 15 of the experiment showed no significant change while those in the 50,100 and $500 \mathrm{mg} / \mathrm{kg}$ groups showed significantly $(\mathrm{p}<0.05)$ lower body weights compared to the control. On day 30 of the experiment, the quails in the $5 \mathrm{mg} / \mathrm{kg}$ group showed no significant $(\mathrm{p}>0.05)$ change in body weight while all other groups showed significant $(p<0.05)$ lowering of the body weight when compared with that of the control group. On day 90, the quails in all treatment groups showed a significant $(p<0.05)$ decrease in body weight in comparison with the control group.

\section{Relative weight of the liver and testes and volume of testes}

On day 90, the relative weights of liver in the 5,25 , 50 and $100 \mathrm{mg} / \mathrm{kg}$ groups were significantly $(\mathrm{p}<0.05)$ higher than that of the control group. The differences in the relative weights of the testes (Figure $2 a$ ) on day 15 of the experiment were not significant among all the 


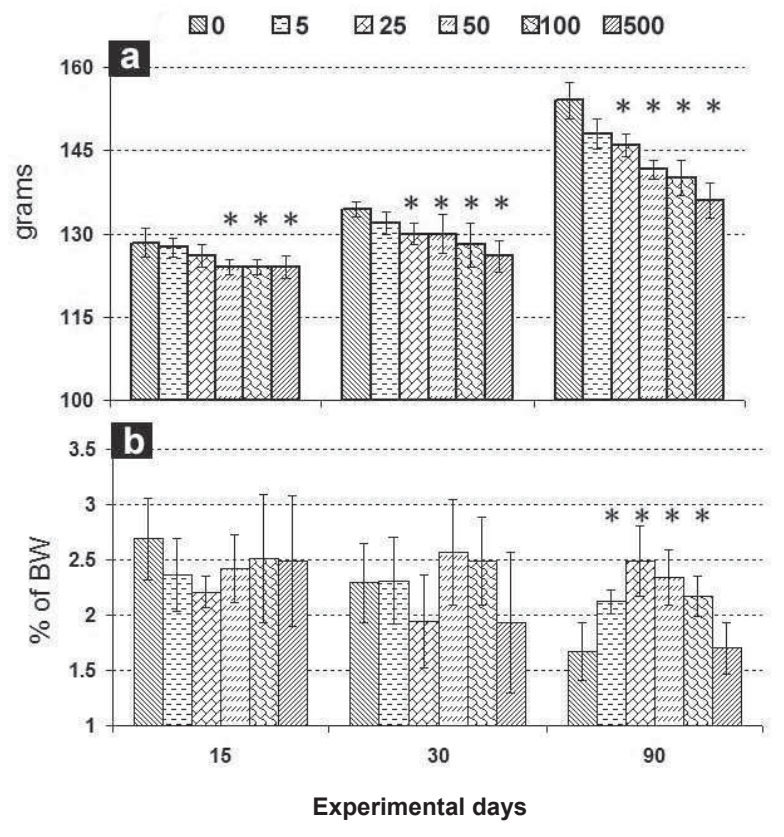

Figure 1. Effect of different exposure levels of endosulfan in feed on a) the body weight and b) the relative weight of liver, in male Japanese quails

groups. On day 30 , the 50,100 and $500 \mathrm{mg} / \mathrm{kg}$ groups had significantly $(\mathrm{p}<0.05)$ low relative weights of testes than the control group. On day 90, all treatment groups had significantly $(\mathrm{p}<0.05)$ low relative weights of testes than that of the control.

The volume of the testes (Figure $2 \mathrm{~b}$ ) on day $15 \mathrm{did}$ not show significant differences among the groups. On day 30 , the testes volume in the 50,100 and $500 \mathrm{mg} / \mathrm{kg}$ groups were significantly $(\mathrm{p}<0.05)$ low while the 5 and $25 \mathrm{mg} / \mathrm{kg}$ groups were not significantly different from the control. On day 90, all treatment groups (5 to $500 \mathrm{mg} / \mathrm{kg}$ ) showed non significant lowering of testes volume compared to the control group.

\section{Diameter of seminiferous tubules}

On day 15, diameter of the seminiferous tubules (Figure 2c) of quails in all treated groups (5 to $500 \mathrm{mg} / \mathrm{kg}$ ) showed non-significant differences from that of the control. On days 30 and 90, all treated ( 5 to $500 \mathrm{mg} / \mathrm{kg}$ ) groups had significantly $(\mathrm{p}<0.05)$ lower values than the control group except the $5 \mathrm{mg} / \mathrm{kg}$ group, which showed a non-significant difference at 90 days.

\section{Haematological and biochemical parameters}

Total leukocyte counts and erythrocyte counts on day 15 were significantly $(\mathrm{p}<0.05)$ lower in the 25 and

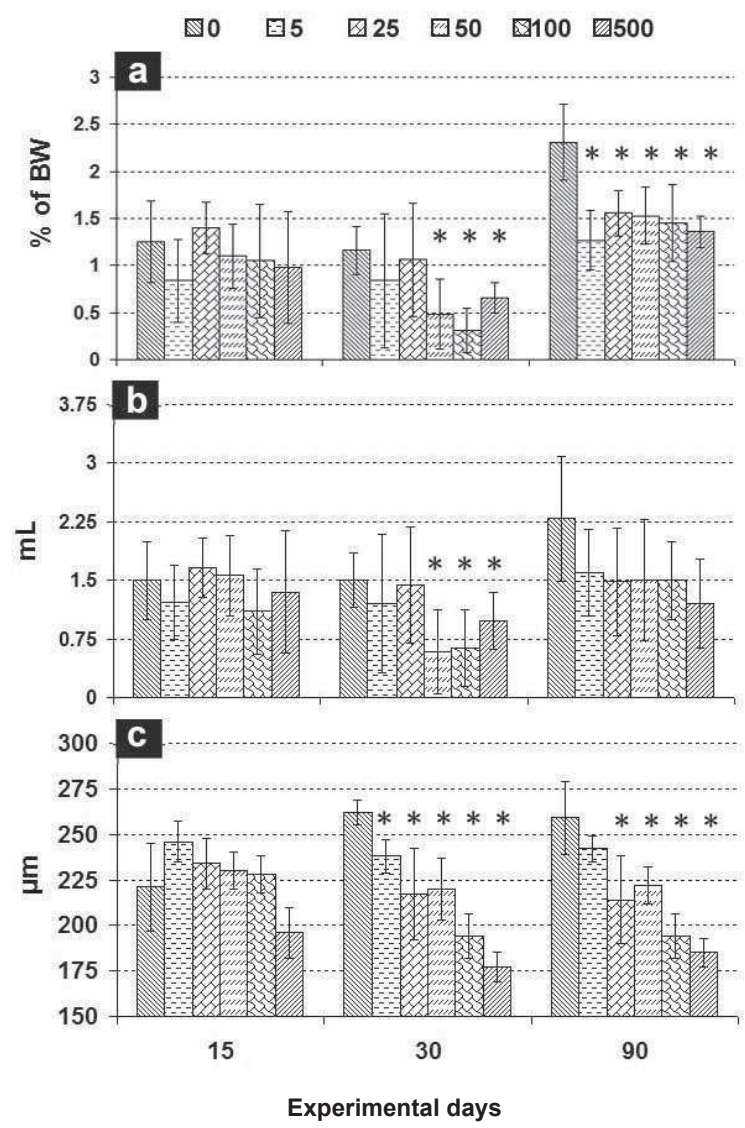

Figure 2. Effect of different exposure levels of endosulfan in feed on a) the relative weight of testes, b) testes volume and c) diameter of seminiferous tubules, in male Japanese quails

$50 \mathrm{mg} / \mathrm{kg}$ groups compared to the control (Table 2). On days 30 and 90, erythrocyte counts in the 50,100 and $500 \mathrm{mg} / \mathrm{kg}$ groups were significantly $(\mathrm{p}<0.05)$ lower than those in the control. On day 30 , all the experimental groups had significantly $(\mathrm{p}<0.05)$ lower leukocyte counts than the control group. On day 90 , the leukocyte and erythrocyte counts in the 50 and $500 \mathrm{mg} / \mathrm{kg}$ groups were significantly $(\mathrm{p}<0.05)$ lower than that of the control group. Haematocrit values (Table 2) decreased in the 100 and $500 \mathrm{mg} / \mathrm{kg}$ groups compared to the control on all the days, whereas haematocrit values of 25 and $50 \mathrm{mg} / \mathrm{kg}$ groups were significantly $(\mathrm{p}<0.05)$ decreased on days 30 and 15. Differences in the haemoglobin concentration on all occasions were not significant in all treatment groups compared to the control.

Serum total protein (Table 3) of 25 and $100 \mathrm{mg} / \mathrm{kg}$ groups was significantly $(p<0.05)$ lower than that of the other groups on day 15 . On day 30 the 25,100 and $500 \mathrm{mg} / \mathrm{kg}$ groups had significantly $(\mathrm{p}<0.05)$ lower values than the control group. On day 90 , only the 25 , 
Table 2: Effect of different dose levels of endosulfan in feed on different haematological parameters (mean \pm SD) in male Japanese quails

\begin{tabular}{|c|c|c|c|c|c|c|}
\hline \multirow{2}{*}{$\begin{array}{l}\text { Parameters/ } \\
\text { Period (days) }\end{array}$} & \multicolumn{6}{|c|}{ Groups } \\
\hline & A & B & $\mathrm{C}$ & $\mathrm{D}$ & $\mathrm{E}$ & $\mathrm{F}$ \\
\hline \multicolumn{7}{|c|}{ Erythrocytes $\left(10^{6} / \mu \mathrm{L}\right)$} \\
\hline 15 & $4.67 \pm 0.25$ & $4.45 \pm 0.31$ & $4.64 \pm 0.21$ & $4.21 \pm 0.27 *$ & $4.47 \pm 0.26$ & $4.49 \pm 0.36$ \\
\hline 30 & $4.78 \pm 0.32$ & $4.66 \pm 0.11$ & $4.61 \pm 0.17$ & $4.40 \pm 0.27 *$ & $4.07 \pm 0.16^{*}$ & $4.20 \pm 0.28^{*}$ \\
\hline 90 & $4.86 \pm 0.08$ & $4.68 \pm 0.12$ & $4.46 \pm 0.23$ & $4.33 \pm 0.21 *$ & $4.17 \pm 0.199 *$ & $3.94 \pm .39^{*}$ \\
\hline \multicolumn{7}{|c|}{ Leukocytes $\left(10^{3} / \mu \mathrm{L}\right)$} \\
\hline 15 & $8.26 \pm 0.88$ & $8.11 \pm 1.79$ & $7.16 \pm 1.02 *$ & $7.36 \pm 0.42$ & $6.91 \pm 0.62$ & $6.78 \pm 0.54$ \\
\hline 30 & $8.90 \pm .850$ & $7.49 \pm 1.01^{*}$ & $6.99 \pm 0.81^{*}$ & $7.55 \pm 0.83^{*}$ & $6.81 \pm 0.42 *$ & $6.80 \pm 0.43 *$ \\
\hline 90 & $9.08 \pm 0.46$ & $9.29 \pm 1.15$ & $8.97 \pm 1.29$ & $7.95 \pm 0.47^{*}$ & $8.27 \pm 0.59$ & $8.01 \pm 0.19^{*}$ \\
\hline \multicolumn{7}{|c|}{ Haematocrit (\%) } \\
\hline 15 & $33.00 \pm 1.79$ & $31.67 \pm 2.73$ & $31.17 \pm 0.93$ & $30.67 \pm 1.03 *$ & $29.33 \pm 1.21 *$ & $28.50 \pm 1.52 *$ \\
\hline 30 & $32.83 \pm 1.83$ & $32.00 \pm 2.10$ & $29.50 \pm 0.84^{*}$ & $31.00 \pm 1.79$ & $29.50 \pm 0.84 *$ & $29.00 \pm 1.79 *$ \\
\hline 90 & $32.33 \pm 1.86$ & $31.17 \pm 0.98$ & $31.33 \pm 1.21$ & $31.00 \pm 1.26$ & $29.83 \pm 1.33 *$ & $29.00 \pm 1.79 *$ \\
\hline \multicolumn{7}{|c|}{ Haemoglobin (g/dL) } \\
\hline 15 & $13.99 \pm 1.65$ & $12.30 \pm 1.93$ & $11.49 \pm 1.19$ & $12.53 \pm 2.32$ & $12.25 \pm 0.99$ & $11.55 \pm 1.06$ \\
\hline 30 & $15.22 \pm 0.84$ & $14.65 \pm 0.86$ & $13.95 \pm 0.93$ & $11.33 \pm 1.02$ & $14.40 \pm 1.05$ & $15.06 \pm 0.78$ \\
\hline 90 & $14.52 \pm 0.95$ & $14.48 \pm 0.82$ & $14.01 \pm 0.97$ & $14.14 \pm 0.82$ & $14.14 \pm 0.86$ & $14.01 \pm 0.58$ \\
\hline
\end{tabular}

Values (mean $\pm \mathrm{SD}$ ) bearing asterisk in a row differ significantly $(\mathrm{p} \leq 0.05)$ than that of the control $(0 \mathrm{mg} / \mathrm{kg}$ group). Endosulfan levels in feed of groups A, B, C, D, E and F were $0,5,25,50,100$ and $500 \mathrm{mg} / \mathrm{kg}$, respectively.

Table 3: Effect of different dose levels of endosulfan in feed on biochemical parameters (mean \pm SD) in male Japanese quails

\begin{tabular}{|c|c|c|c|c|c|c|}
\hline \multirow{2}{*}{$\begin{array}{l}\text { Parameters/ } \\
\text { Period (days) }\end{array}$} & \multicolumn{6}{|c|}{ Groups } \\
\hline & A & B & $\mathrm{C}$ & $\mathrm{D}$ & $\mathrm{E}$ & $\mathrm{F}$ \\
\hline \multicolumn{7}{|c|}{ Serum testosterone (IU) } \\
\hline 90 & $4.43 \pm 2.11$ & $3.66 \pm 2.37$ & $3.43 \pm 1.79$ & $3.01 \pm 1.20$ & $3.15 \pm 1.97$ & $2.58 \pm 2.15$ \\
\hline \multicolumn{7}{|c|}{ Serum total proteins (g/dL) } \\
\hline 15 & $4.04 \pm 0.33$ & $3.84 \pm 0.43$ & $3.19 \pm 0.12 *$ & $3.48 \pm 0.36$ & $3.44 \pm 0.29 *$ & $3.50 \pm 0.44$ \\
\hline 30 & $4.08 \pm 0.39$ & $4.28 \pm 0.30$ & $2.84 \pm 0.91 *$ & $3.28 \pm 0.67$ & $2.68 \pm 0.41^{*}$ & $2.82 \pm 0.66^{*}$ \\
\hline 90 & $4.12 \pm 0.33$ & $3.88 \pm 0.41$ & $3.50 \pm 0.22 *$ & $3.46 \pm 0.26^{*}$ & $3.12 \pm 0.23^{*}$ & $3.48 \pm 0.59$ \\
\hline \multicolumn{7}{|c|}{ Serum albumin $(g / d L)$} \\
\hline 15 & $1.05 \pm 0.22$ & $1.36 \pm 0.26$ & $1.46 \pm 0.42$ & $1.41 \pm 0.41$ & $1.61 \pm 0.01$ & $0.90 \pm 0.23$ \\
\hline 30 & $0.69 \pm 0.35$ & $0.76 \pm 0.25$ & $1.23 \pm 1.14$ & $0.71 \pm 0.25$ & $1.36 \pm 0.39$ & $0.92 \pm 0.33$ \\
\hline 90 & $0.83 \pm 0.07$ & $0.65 \pm 0.20$ & $0.89 \pm 0.26$ & $0.84 \pm 0.23$ & $1.43 \pm 0.36$ & $0.72 \pm 0.37$ \\
\hline
\end{tabular}

Values (mean $\pm \mathrm{SD})$ bearing asterisk in a row differ significantly $(\mathrm{p} \leq 0.05)$ than that of the control $(0 \mathrm{mg} / \mathrm{kg}$ group). Endosulfan levels in feed of groups A, B, C, D, E and F were $0,5,25,50,100$ and $500 \mathrm{mg} / \mathrm{kg}$, respectively.

50 and $100 \mathrm{mg} / \mathrm{kg}$ groups had significantly $(\mathrm{p}<0.05)$ lower values while the other groups showed differences that were not significant when compared to the control group. The serum albumin concentration of all treatment groups showed no significant differences from the control group on days 15,30 and 90 of the experiment. The serum testosterone concentration of all treatment groups decreased with the increase in dietary levels of endosulfan. However, the differences compared to the control were non significant (Table 3). 


\section{Gross and histopathological lesions}

No gross lesions were observed in the different visceral organs of quails in the groups that were given endosulfan at different dietary dose levels. The histological pattern of liver tissues of quails of the control group did not show any deviation from the normal on day 15, 30 and 90 of the experiment. Livers of quails in all endosulfan treated groups exhibited fatty change of hepatocytes and congestion of blood vessels in hepatic parenchyma on day 15 and 30 (Figure 3 ). In addition to these, livers of the quails in the 50,100 and $500 \mathrm{mg} / \mathrm{kg}$ groups also showed hepatocyte necrosis on day 30. On day 90 of the experiment, livers of these groups exhibited areas of hepatic necrosis.

Seminiferous tubules of the testes of birds in the control group sacrificed on days 15,30 and 90 had normal histological pattern (Figure 4). In the $5 \mathrm{mg} / \mathrm{kg}$ group, on day 15 and 30 , the microscopic picture of the testes was

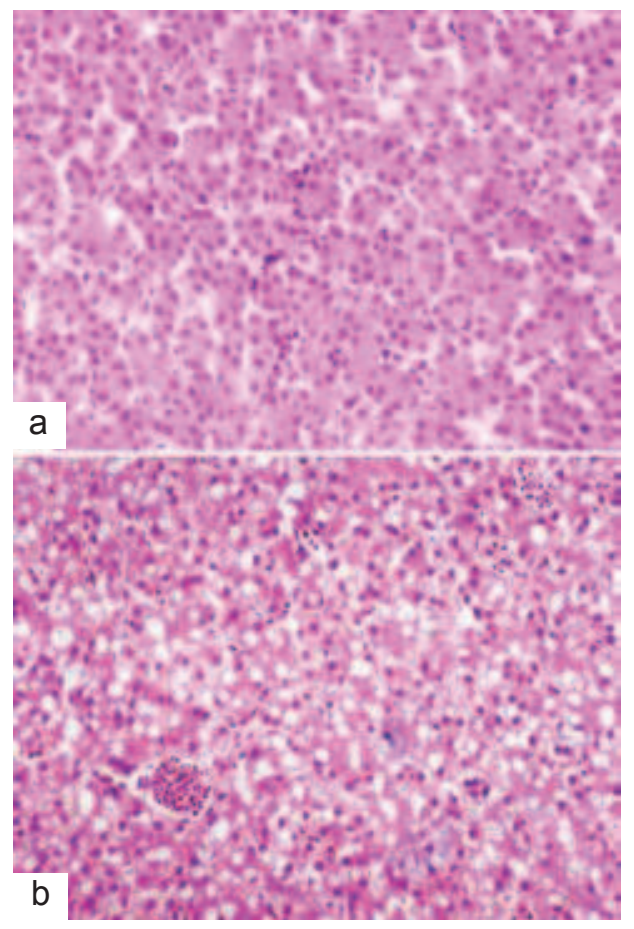

Figure 3. Photomicrograph of liver of a male Japanese quail. Hepatocytes a) without any pathologic lesion (control) and b) hepatocytes showing fatty change at $50 \mathrm{mg}$ endosulfan $/ \mathrm{kg}$ for 15 days exposure level. H \& E stain, X200. the same as in the control. On day 90 of the experiment, semeniferous tubules of $50 \%$ of the birds in the $5 \mathrm{mg} / \mathrm{kg}$ group exhibited degenerated spermatids characterized by dark shrunken nuclei. Multinucleated cells having 2-4 nuclei were present in the lumen of some seminiferous tubules. In the $25 \mathrm{mg} / \mathrm{kg}$ group on day 15 , multinucleated cells and desquamated apoptotic spermatids were present in the germinal epithelium in $50 \%$ of the birds. On day 30, all birds in this group exhibited spermatozoa with rounded heads and condensed, dark nuclei in spermatids. On day 90, degenerated spermatids and

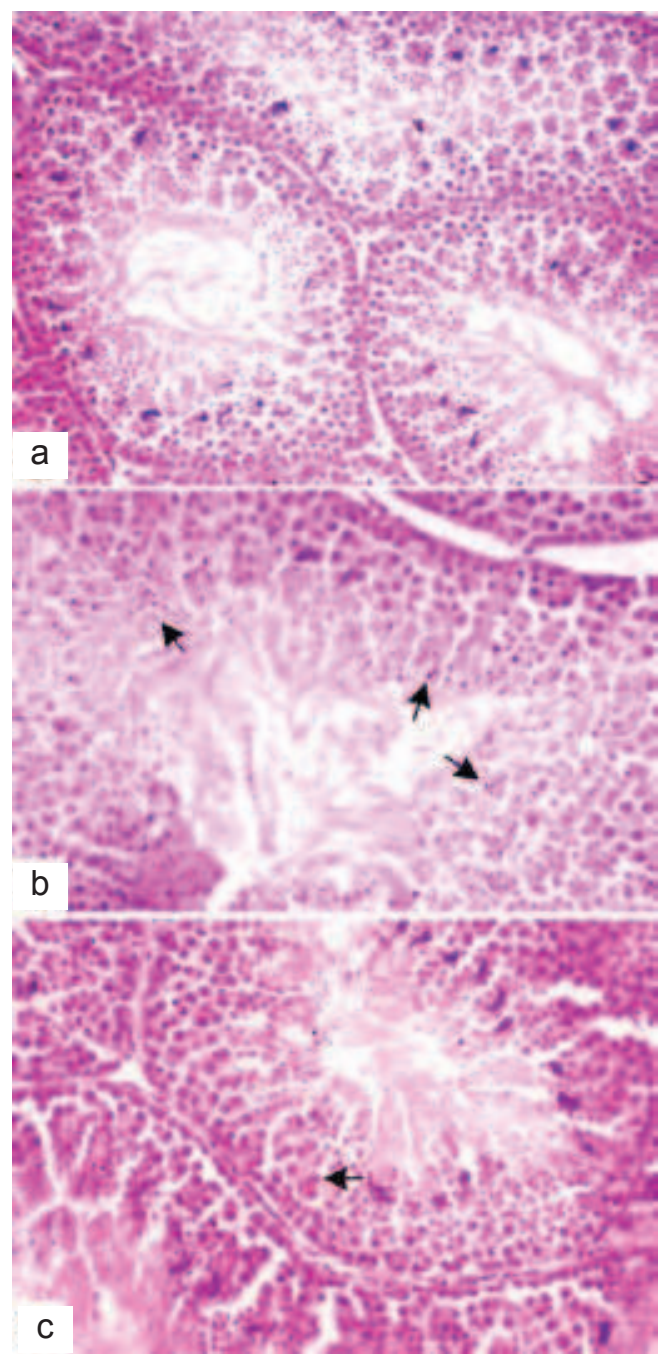

Figure 4. Photomicrograph of testis of a Japanese quail showing a) normal spermatogenesis (control group), b) condensed and dark nuclei of spermatids (arrows) and c) multinucleated cells (arrow) in germinal epithelium layer of seminiferous tubule. Endosulfan exposure level was $25 \mathrm{mg} / \mathrm{kg}$ feed for 30 (b) and 90 days (c). H \& E stain, X200. 
spermatozoa having rounded heads and multinucleated cells were observed in the germinal epithelial layer of the seminiferous tubules (Figure 4). All the birds in 50, 100 and $500 \mathrm{mg} / \mathrm{kg}$ groups had histological alterations similar to those in the $25 \mathrm{mg} / \mathrm{kg}$ group. Testes in the 100 and $500 \mathrm{mg} / \mathrm{kg}$ groups at day 90 of the experiment also exhibited increased cellular debris and multinucleated cells in the lumen of the tubules.

\section{DISCUSSION}

Nervous excitement of the quails was a prominent clinical sign in the 100 and $500 \mathrm{mg} / \mathrm{kg}$ groups. Nervous excitement following administration of endosulfan has been reported earlier in pigeons (Anand et al., 1986) and rats (Dikshith et al., 1988). In human beings nervous excitement, tonic and clonic seizures have also been described following ingestion of endosulfan (Yavuz et al., 2007). Japanese quails given 1000, 2000 and $4000 \mathrm{mg} / \mathrm{kg}$ of endosulfan containing feed have shown lethargy, weakness and diarrhoea (Prakash et al., 2009). The mild depression in low dose groups (25 and $50 \mathrm{mg} / \mathrm{kg}$ ) could be a consequence of general toxic effects associated with organochlorine pesticides. Bhalla and Thami (2004) mentioned dizziness, seizures and nervous system damage after accidental ingestion or industrial exposure of lindane (an organochlorine).

In the present study, dose-related significant reduction in the intake of feed treated with endosulfan was observed. The decrease in feed consumption may be attributed to either the biological effect of endosulfan or due to low palatability of the treated feed (Prakash et al., 2009). A significant endosulfan dose-related decrease in body weight was observed in the present study. The reduction in body weight could be due to decreased feed consumption (Prakash et al., 2009) or due to general toxicity of endosulfan. A decrease in body weight has also been reported in rats (Chitra et al., 1999). However, in broiler chicks feeding on $2 \mathrm{mg} / \mathrm{kg}$ chlorinated pesticide for 8 weeks did not affect the body weight (Garg et al., 2004a), which might be due to low dietary levels of endosulfan or species variation. Pathological changes observed in the liver in the present study have also been reported in rats (Choudhary et al., 2003) and fish (Nowak, 1996) but not in avian species.

Haematological parameters responded to endosulfan toxicity by a significant decrease in erythrocyte and total leukocyte counts along with a decrease in haematocrit levels at and above $100 \mathrm{mg} / \mathrm{kg}$ endosulfan treated feed. These observations suggest the inhibitory effect of endosulfan on haematopoietic systems in Japanese quails. A dose of 2 ppm dietary endosulfan for 8 weeks had no effect upon haematological parameters in broiler chicks (Garg et al., 2004a). Similarly, no significant difference has been detected in blood parameters of 44 persons accidentally intoxicated by ingestion of endosulfan contaminated food (Venkateswarlu et al., 2000). The possible reason for no effect of endosulfan on haematological parameters as reported by some studies could be due to the low dose of endosulfan (2 ppm) compared to the present study (at and above $100 \mathrm{mg} / \mathrm{kg}$ endosulfan/kg feed).

A decrease in serum total proteins and albumin, observed in quails following endosulfan feeding has also been reported in fish (Gill et al., 1991). Serum protein synthesis mainly takes place in the liver and is impaired due to many pathological conditions of liver (Latimer et al., 2003). The degenerative pathomorphological changes observed in the liver of endosulfan fed quails in the present study might have resulted in low serum protein concentration.

In the present study, harmful effect of endosulfan upon the male reproductive system of Japanese quail was evident by pathomorphological alterations in testes characterized by a low relative weight, low volume, decreased diameter of seminiferous tubules, and presence of degenerated round spermatids and multinucleated cells in germinal epithelium and lumen of the seminiferous tubules. A decrease in spermatogenesis by exposure of rats to endosulfan has been reported (Dalsenter et al., 1999). In male Japanese quails, crowing behaviour is strictly androgen dependent (Chiba \& Hosokawa, 2006). Crowing, foamy droppings and mounting are the indications of onset of sexual maturity in male Japanese quails (Adkins-Regan, 1999). Delayed onset of these signs in Japanese quails suggested delayed onset of puberty or slowing of timing of reproductive maturation. An endosulfan induced delay in onset of puberty has been reported in boys (Saiyed et al., 2003; Roy et al., 2009). In the present study, serum testosterone concentration did not show significant differences among different treatment groups, indicating that delayed onset of sexual maturity might not be related to testosterone levels. Decreased testosterone and steriodegenic enzyme activity in rats have also been reported (Singh \& Pandey, 1990).

Although there are no reports of endosulfan induced pathological effects upon male reproductive system of avian species, the gonadotoxic effects of endosulfan upon male reproductive system of rats have been documented. These changes included a decrease in 
testes weight, spermatogenic cell population, total sperm count, sperm motility and increase in the number of abnormal spermatozoa (Pandey et al., 1990; Rao et al., 2005). In addition to the above alterations, absence of spermatids and presence of multinucleated cells in germinal epithelium of endosulfan treated rats have also been reported (Jaiswal et al., 2005). Smaller weights and volumes of testes, smaller diameter of seminiferous tubules, necrosis of spermatids and multinucleated cells in the germinal epithelium observed in Japanese quails in the present study fairly corresponds with the findings reported in testes of rats administered endosulfan from 2.5 to $10 \mathrm{mg} / \mathrm{kg}$ body weight for variable periods of time (Rao et al., 2005).

\section{REFERENCES}

1. Adkins-Regan E. (1999). Foam produced by male coturnix quail: what is its function? The Auk 116:184-193.

2. Aggarwal M., Naraharisetti S.B., Sarkar S.N., Rao G.S., Degen G.H. \& Malik J.K. (2009). Effects of subchronic coexposure to arsenic and endosulfan on the erythrocytes of broiler chickens: a biochemical study. Archives of Environmental Contamination and Toxicology 56: $139-148$.

3. Ahmad L., Khan A., Khan M.Z. \& Hussain I. (2009). Cypermethrin induced anemia in male rabbits. Pakistan Veterinary Journal 29: 191-195.

4. Anand M., Agrawal A.K., Gopal K., Sur R.N. \& Seth P.K. (1986). Endosulfan and cholinergic (muscarinic) transmission: effect on electroencephalograms and $[3 \mathrm{H}]$ quinuclidinyl benzilate in pigeon brain. Environmental Research 40: 421- 426.

5. Awaad M.H.H., Abdel-Alim G.A., Sayed K.S.S., Kawkab Ahmed A., Nada A.A., Metwalli A.S.Z. \& Alkhalaf A.N. (2010). Immunostimulant effects of essential oils of peppermint and eucalyptus in chickens. Pakistan Veterinary Journal 30: 61- 66.

6. Bhalla M. \& Thami G.P. (2004). Reversible neurotoxicity after an overdose of topical lindane in an infant. Pediatric Dermatology 21: 597-599.

7. Brannen K.C., Devaud L.L., Liu J. \& Lauder J.M. (1998). Prenatal exposure to neurotoxicants dieldrin or lindane alters tert-butylbicyclophosphorothionate binding to GABAA receptors in fetal rat brainstem. Developmental Neuroscience 20: $34-41$.

8. Chiba A. \& Hosokawa N. (2006). Effects of androgens and estrogens on crowing and distress callings in male Japanese quail, Coturnix japonica. Hormones and Behavior 49: 4-14.

9. Chitra K.C., Latchoumycandane C. \& Mathur P.P. (1999). Chronic effects of endosulfan on the testicular functions of rat. Asian Journal of Andrology 1: 203-206.

10. Choudhary N., Sharma M., Verma P. \& Joshi S.C. (2003). Hepato and nephrotoxicity in rat exposed to endosulfan. Journal of Environmental Biology 24: 305 -308.

11. Cid F.D., Anton R.I. \& Caviedes-Vidal E. (2007).
Organochlorine pesticide contamination in three bird species of the Embalse La Florida water reservoir in the semiarid Midwest of Argentina. The Science of the Total Environment 385: 86 - 96.

12. Dalsenter P.R., Dallegrave E., Mello J. Rb., Langeloh A., Oliveira R.T. \& Faqi A.S. (1999). Reproductive effects of endosulfan on male offspring of rats exposed during pregnancy and lactation. Human and Experimental Toxicology 18: $583-589$.

13. Dikshith D.S., Raizada R.B., Kumar S.N., Srivastava M.K., Kaushal R.A., Singh R.P. \& Gupta K.P. (1988). Effect of repeated dermal application of endosulfan to rats. Veterinary and Human Toxicology 30: 219-224.

14. Garg U.K., Pal A.K., Jha G.J. \& Jadhao S.B. (2004a). Haemato-biochemical and immuno-pathophysiological effects of chronic toxicity with synthetic pyrethroid, organophosphate and chlorinated pesticides in broiler chicks. International Immunopharmacology 4: $1709-1722$.

15. Garg U.K., Pal A.K., Jha G.J. \& Jadhao S.B. (2004b). Pathophysiological effects of chronic toxicity with synthetic pyrethroid, organophosphate and chlorinated pesticides on bone health of broiler chicks. Toxicologic Pathology 32: $364-369$.

16. Gill T.S., Pande J. \& Tewari H. (1991). Effects of endosulfan on the blood and organ chemistry of freshwater fish, Barbus conchonius Hamilton. Ecotoxicology and Environmental Safety 21: $80-91$.

17. Jaiswal A., Parihar V.K., Kumar M.S., Manjula S.D., Krishnanand B.R., Shanbhag R. \& Unnikrishnan M.K. (2005). 5-Aminosalicylic acid reverses endosulfaninduced testicular toxicity in male rats. Mutation Research 585: 50 -59.

18. Jalees M.M., Khan M.Z., Saleemi M.K. \& Khan A. (2011). Effects of cottonseed meal on hematological, biochemical and behavioral alterations in male Japanese quail (Coturnix japonica). Pakistan Veterinary Journal 31: 211- 214.

19. Karatas A.D., Aygun D. \& Baydin A. (2006). Characteristics of endosulfan poisoning: a study of 23 cases. Singapore Medicine Journal 47: 1030 -1032.

20. Khan A., Ullah M. \& Khan M.Z. (2008). Pathological effects of sodium hypochlorite administration through drinking water in male Japanese quails (Coturnix japonica). Human and Experimental Toxicology 27: 773 -780.

21. Khan R.U., Durrani F.R., Chand N. \& Anwar H. (2010). Influence of feed supplementation with Cannabis sativa on quality of broilers carcass. Pakistan Veterinary Journal 30: $34-38$.

22. Latimer K.S., Mahaffey E.A. \& Prasse K.W. (2003). Clinical Pathology Veterinary Laboratory Medicine, $4^{\text {th }}$ edition. Iowa State Press, Iowa, USA.

23. Mehta G., Singh S.P., Pandey S.K. \& Sharma L.D. (2008). Cytotoxic response of endosulfan and chlorpyrifos pesticides in poultry lymphocyte culture. Toxicology International 15: 97-101.

24. Mora M.A. \& Anderson D.W. (1991). Seasonal and geographical variation of organochlorine residues in birds from northwest Mexico. Archives of Environmental Contamination and Toxicology 21: 541-548. 
25. Muralidharan S., Dhananjayan V., Risebrough R., Prakash V., Jayakumar R. \& Bloom P.H. (2008). Persistent organochlorine pesticide residues in tissues and eggs of white-backed vulture, Gyps bengalensis from different locations in India. Bulletin of Environmental Contamination and Toxicology 81: 561-565.

26. Naqvi S.M. \& Vaishnavi C. (1993). Bioaccumulative potential and toxicity of endosulfan insecticide to nontarget animals. Comparative Biochemistry and Physiology 105: 347-361.

27. Nowak B. (1996). Relationship between endosulfan residue level and ultrastructural changes in the liver of catfish, Tandanus tandanus. Archives of Environmental Contamination and Toxicology 30: 195 -202.

28. Pandey N., Gundevia F., Prem A.S. \& Ray P.K. (1990). Studies on the genotoxicity of endosulfan, an organochlorine insecticide in mammalian germ cells. Mutation Research 242: $1-7$.

29. Prakash P.J., Rajashekher G., Krishnappa H., Sulaiman S.M. \& Rao K.V. (2009). Acute toxic effects of endosulfan 35 EC (Endocel) upon gavage and dietary admixture in Japanese quails. Research Journal of Environmental Toxicology 3: $124-131$.

30. Rao M., Narayana K., Benjamin S. \& Bairy K.L. (2005). L-ascorbic acid ameliorates postnatal endosulfan induced testicular damage in rats. Indian Journal of Physiology and Pharmacology 49: 331-336.

31. Reuber M.D. (1981). The role of toxicity in the carcinogenicity of endosulfan. The Science of the Total Environment 20: 23 - 47.
32. Roy J.R., Chakraborty S. \& Chakraborty T.R. (2009). Estrogen-like endocrine disrupting chemicals affecting puberty in humans-a review. Medical Science Monitor 15: $137-145$

33. Saiyed H., Dewan A., Bhatnagar V., Shenoy U., Shenoy R., Rajmohan H., Patel K., Kashyap R., Kulkarni P., Rajan B. \& Lakkad B. (2003). Effect of endosulfan on male reproductive development. Environmental Health Perspectives 111: $1958-1962$.

34. Shalini S., Dureja P. \& Kumar S. (2000). Biodegradation of alpha and beta isomers of endosulphan and endosulphan sulphate in Indian soils. Journal of Environmental Science and Health 35: 337-346.

35. Singh S.K. \& Pandey R.S. (1990). Effect of sub-chronic endosulfan exposures on plasma gonadotrophins, testosterone, testicular testosterone and enzymes of androgen biosynthesis in rat. Indian Journal of Experimental Biology 28: 953 - 956.

36. Slotkin T.A., MacKillop E.A., Ryde I.T., Tate C.A. \& Seidler F.J. (2007). Screening for developmental neurotoxicity using PC12 cells: comparisons of organophosphates with a carbamate, an organochlorine, and divalent nickel. Environmental Health Perspectives 115: 93 - 101.

37. Venkateswarlu K., Suryarao K., Srinivas V., Sivaprakash N., Jagannadharao N.R. \& Mythilai A. (2000). Endosulfan poisoning-a clinical profile. Journal of the Association of Physicians of India 8: 323 - 325.

38. Yavuz Y., Yurumez Y., Kücüker H., Ela Y. \& Yüksel S. (2007). Two cases of acute endosulfan toxicity. Clinical Toxicology (Philadelphia, PA) 45: 530 - 532. 